\title{
Air Pollution in the Brazilian Road Transport and Its Environmental and Social Consequences
}

\author{
Geórgia Amaral Mothé1, Marcelo Silva Sthel ${ }^{*}$, Maria Priscila Pessanha de Castro1, \\ Rosane Toledo$^{1}$, Alexandre Stumbo², Marcelo Gomes ${ }^{1}$, Israel Esquef ${ }^{1}$, Helion Vargas ${ }^{1}$ \\ ${ }^{1}$ Laboratory of Physical Sciences, North Fluminense State University, Center for Science and Technology, \\ Campos dos Goytacazes, Brazil \\ ${ }^{2}$ Laboratory of Chemical Sciences, North Fluminense State University, Center for Science and Technology, \\ Campos dos Goytacazes, Brazil \\ Email: sthel@uenf.br
}

Received 3 September 2014; revised 1 October 2014; accepted 24 October 2014

Copyright (C) 2014 by authors and Scientific Research Publishing Inc.

This work is licensed under the Creative Commons Attribution International License (CC BY). http://creativecommons.org/licenses/by/4.0/

(c) (i) Open Access

\section{Abstract}

The use of fossil fuels has been greatly increased since the eighteenth century with advent of the industrial revolution. Currently, the use of these fuels is responsible for, on average, $80 \%$ of energy generation in human society, producing large emission of pollutant gases and particulate material. Thus the transport sector is a major source of air pollution worldwide. This issue causes serious damages to the environment through phenomena such as acid rain, global warming and photochemical smog. Moreover, the emission of pollutants is also related to damages in human health. Brazil is a country with great territorial dimensions and its transport array is eminently by road, so it is a major consumer of fossil fuels, such as diesel, which has been producing serious environmental and social problems. Thus, this paper presents an analysis of the emission of gaseous pollutants and particulate matter from the transport sector (buses and trucks), gaseous pollutants such as $\mathrm{NO}_{2}$ and $\mathrm{SO}_{2}$ were detected in ppmv concentrations using electrochemical sensors. The composition constituents of the particulate materials emitted in diesel combustion and their respective concentrations were determined by $\mathrm{X}$ rays fluorescence spectrometry (XRF). The identified elements were: $\mathrm{S}, \mathrm{Fe}, \mathrm{Si}, \mathrm{Ca}, \mathrm{Zn}, \mathrm{P}, \mathrm{Ni}, \mathrm{Cr}, \mathrm{Ti}, \mathrm{Mn}$ and $\mathrm{Cu}$.

\section{Keywords}

Pollutant Gases, Particulate Materials, Electrochemical Sensors, X-Ray Fluorescence

\footnotetext{
"Corresponding author.
}

How to cite this paper: Mothé, G.A., Sthel, M.S., de Castro, M.P.P., Toledo, R., Stumbo, A., Gomes, M., Esquef, I. and Vargas, H. (2014) Air Pollution in the Brazilian Road Transport and Its Environmental and Social Consequences. Journal of Environmental Protection, 5, 1466-1476. http://dx.doi.org/10.4236/jep.2014.515139 


\section{Introduction}

The transport sector is an important segment of the global economy in which fossil fuels are used in large quantities. The use of this type of fuel contributes to worsening air pollution, which is one of today's main environmental problems, due to its correlation with severe atmospheric phenomena (global warming), causing the dreaded climate change [1]-[10], severely impacting biodiversity and modifying the planet biogeochemical cycles [11]-[19].

The transportation sector seriously impacts the environment due to its great expansion in recent decades and the use of diesel oil in a large scale. Diesel fuel, during its combustion, generates large amounts of greenhouse gases such as Volatile Organic Compounds (VOCs), carbon monoxide (CO), nitrogen dioxide $\left(\mathrm{NO}_{2}\right)$, sulfur dioxide $\left(\mathrm{SO}_{2}\right)$, carbon dioxide $\left(\mathrm{CO}_{2}\right)$, nitrogen monoxide (NO) and others [20]-[22].

The particulate material (PM) released into the atmosphere is generally invisible to the naked eye, but once treated collectively, these small particles form a mist which reduces the visibility. Burning fossil fuels is one of the most important sources of particulate material, especially in diesel engines [23]-[26] where its emission is related to the burning of diesel and lubricant oil, besides the bearing and engine materials wear.

According to Bosch [27], particulate material emission in diesel cycle engines is considerably larger than that in Otto cycle engines. Thus, once there is a large concentration of particulate material in diesel bus and truck exhausts, the chemical composition of these particles requires further investigation, since its composition is poorly known. Therefore, it is important to use sensitive and selective methodologies and techniques to identify pollutant gases and chemical species in the particulate material.

Brazilian transportation network is eminently by road, so this country presents enormous traffic congestion in large urban centers, which increases air pollution. There is also a government policy of encouraging the acquisition of vehicles for individual use rather than investing in public transport, which has caused chaos in major cities of the country. On June, 2013, a great number of protests started in São Paulo and quickly spread throughout many Brazilian cities, questioning the rising cost of tickets and the poor quality of the urban mass transportation [28]-[30]. Therefore, this option by road mass transport is reaching its limits, because it presents clear signs of saturation, which has been generating serious socio-political crisis in Brazil. The air pollution in large cities is another worrying factor due to the heavy use of road transport, which is seriously impacting population health [23]-[25] [31]-[38].

The operation of the Brazilian economy is closely linked to the maintenance of a large fleet of trucks and buses, since this country has a large territorial area and has prioritized the road transport. Brazilian domestic consumption of diesel is estimated to be around 40 billion liters per year, and $82.4 \%$ of this consumption is used only in the transportation sector [39].

The purpose of this study is to analyze the emission concentrations of $\mathrm{NO}_{2}$ and $\mathrm{SO}_{2}$ gases and determine the composition of particulate matter from exhaust of diesel vehicles (buses and trucks). These gases have an environmental importance to Brazil due to the fact that nitrogen oxides $\left(\mathrm{NO}_{\mathrm{x}}\right)$ and VOCs in the presence of solar radiation, generate tropospheric ozone $\left(\mathrm{O}_{3}\right)$ [40]-[42], which is considered a secondary pollutant and a major constituent of photochemical smog. Brazil is a tropical country with intense solar radiation throughout the year, which eases the formation of $\mathrm{O}_{3}$. $\mathrm{NO}_{2}$ and $\mathrm{SO}_{2}$ are generating acid rain [43] [44].

Several authors have pointed the harmful effects of air pollution on human health [33] [37] [45]-[47]. In Brazil, the situation is aggravated in the main metropolis, São Paulo, mainly by the transport model adopted in the country [24] [25] [31] [32] [34] [36]-[38] [42] [45]-[49].

In another initiative to reduce the use of diesel damage to the environment, Petrobras, a Brazilian state oil company, has developed a program to reduce the presence of $\mathrm{SO}_{2}$ and sulfur in the formation of particulate material in large Brazilian cities. The D-500S diesel was then developed. This fuel, which is commercialized in Brazilian metropolitan regions, has 500 ppm of sulfur in its formulation, much better than the D-2000, which is commercialized in non-metropolitan regions (inside the country) and has 2000 ppm of sulfur in its formulation.

In this context, this paper presents a study of the emissions of pollutant gases and particulate material from diesel engines (buses and trucks) in the city of Campos dos Goytacazes, which is located in northern Rio de Janeiro State. In order to evaluate these emissions, electrochemical sensors were used. These devices detect gas molecules from the redox reaction between the sample and a reagent electrode inside the detector, generating electrical signals, which are proportional to the gas concentration [50].

The X-Ray Fluorescence Spectrometry technique was used to identify the chemical composition of particulate 
material emitted in these engines. This technique premised to indentify the chemical elements and their concentration in samples from bus and truck exhaust. Once it is a non-destructive technique, it was possible to perform a simultaneous analysis of the many elements present in the samples, such as $\mathrm{S}, \mathrm{Fe}, \mathrm{Si}, \mathrm{Ca}, \mathrm{Zn}, \mathrm{P}, \mathrm{Ni}, \mathrm{Cr}, \mathrm{Ti}, \mathrm{Mn}$ and $\mathrm{Cu}$. It was also possible to detect the gases $\mathrm{NO}_{2}$ and $\mathrm{SO}_{2}$ in the ppmv range emitted by buses and trucks using an electrochemical analyzer.

\section{Methodology}

The gas samples collection was performed directly from the exhaust of diesel engines in two different engine operation modes. This methodology is adopted by organs of federal environmental supervision in Brazil as specific legislation [51]. The first one was in the non-accelerated operation mode, with engine rotation speed of about $3000 \mathrm{rpm}$. The second was in the accelerated operation mode, with engine rotation speed of about 6000 $\mathrm{rpm}$. Each collection was performed during 2 minutes at regular intervals of 5 minutes in order to stabilize the motor.

The vehicles used in this study were randomly chosen in order to reproduce the real traffic conditions in a city. The trucks were evaluated in a federal highway (BR-101), which crosses the city and the buses were evaluated during their urban travel, within the boundaries of the city.

\subsection{Electrochemical Sensors}

The Electrochemical sensors used are present in the TEMPEST100® Analyzer (Telegan Gas Monitoring TP20729). The sensors detect the gas concentration from a redox reaction with a specific reagent electrode that is designed for each type of gas to be detected [50] [52] [53].

The analyzer has a suction pump that sucks the sample into its interior. Before contacting sensors, gases first pass through a hose containing a metal tip, which is placed directly on the output of the exhaust pipe of the vehicle. Then, gases go through a double filter system to contain material particles and condensed water vapor. Finally, the sample pass through a small opening, capillary type, and then it is spread by a selective hydrophobic barrier to reach the electrode surface [52] [53].

Within the sensor, there is a resistor connected to the electrodes. After the redox reaction, a current, proportional to the gas concentration, is generated. The reading of the results can be done in real time [50] [52] [53].

\subsection{X-Ray Fluorescence Spectroscopy}

The particles, which were retained in this filtering system in the TEMPEST100® Analyzer were collected, properly stored and taken for XRF analysis.

The X-ray fluorescence Spectroscopy (XRF technique) is considered to be the most useful and disseminated analytical method for determining the presence and the amount of elements present in a given substance. It uses the interaction between X-rays and the matter, and relies on the evaluation of intensity of the characteristic Xrays (number of $\mathrm{X}$-rays detected per time unit) emitted by the elements of a properly excited sample. It is a non-destructive and rapid analysis, one of the most powerful and flexible techniques available for the analysis and characterization of materials, that have been developed during the last decades due to technological and digital advances [54]-[56].

The detection range of the elements vary according to instrument configuration, but typically covers the elements with atomic number equal or greater than 11 (sodium-Na). In some cases, with particular configuration, it is possible to detect lighter elements. It can detect concentrations from $100 \%$ to some ppm, reaching sub-ppm concentrations. Detection limits dependent on the element and the sample matrix, but as a general rule, with heavier elements, better detection limits can be achieved [54]-[56].

When an atom of an element present in the sample is excited, it tends to eject electrons from inner levels and, then, electrons from the outermost levels perform a quantum leap to fill the vacancy. Each electronic transition constitutes a loss of energy for the electron and the energy is emitted as a X-ray photon with characteristic energy and it can be used to identify the light emitting element. Basically X-ray fluorescence spectroscopy analysis consists of three steps: excitation of elements in the sample, scattering of emitted characteristic X-rays and detecting and measuring those $\mathrm{X}$-rays.

The dispersion methods used in most X-ray spectrometers are classified into two types: wavelength dispersion 
(WDXRF) and energy dispersion (EDXD). Each method has its own advantages and disadvantages. At the wavelength dispersion, the characteristic X-rays are selected by a crystal analyzer, according to their wavelengths, obeying the Bragg diffraction law. For the energy dispersion method, X-rays are selected through electronic pulses produced in a suitable detector, where the amplitudes of these pulses are directly proportional to the X-rays energies [54]-[56]. In this study, an energy dispersion spectrometer from Shimadzu was used.

\section{Results and Discussion}

According to the Traffic Department of the State of Rio de Janeiro (DETRAN/RJ), until March 2014, there were 14,299 registered diesel vehicles in Campos dos Goytacazes. In Brazil, this number is biggest than 320,000. This number has been increasing over the years in the city and in the entire country, as seen in the Figure 1 and Figure 2, respectively. Another worrying factor is the average age of these vehicles: most of them have over than 20 years of use. The scrapped fleet increases pollutants emissions due to the poor maintenance condition of these vehicles [51].

This experiment aimed to reproduce the dynamics of real traffic in a city. So, the choice of vehicles was random in order to check the present gases in situ, without the need to standardize the vehicles.

Table 1 shows the results for $\mathrm{NO}_{2}$ and $\mathrm{SO}_{2}$ emissions gases from the exhaust of 8 buses in the city of Campos dos Goytacazes. These buses are part of the city's public transportation fleet. They were manufactured between 1980 and 2006. The buses were supplied with D-2000, which is marketed in non-metropolitan regions (inside the country) and has $2000 \mathrm{ppm}$ of sulfur in its formulation.

Analyzing $\mathrm{NO}_{2}$ emissions, we can notice that this gas was emitted mostly in the accelerated operation mode than in the non-accelerated mode (Figure 3), possibly due to higher fuel consumption in higher engine rotation speed. The $\mathrm{NO}_{2}$ concentrations emitted by the analyzed buses varied in a range of 4 - 868 ppmv. Once the minibuses have less powerful engines, they burn less fuel. Then, they emitted lower $\mathrm{NO}_{2}$ concentrations.

Analyzing $\mathrm{SO}_{2}$ emissions, one can notice that, in the accelerated operation mode, this gas also presented higher concentrations than in non-accelerated operation mode (Figure 4). Only two buses (1 and 3) presented an opposite trend behavior. The lowest concentrations of $\mathrm{SO}_{2}$ emissions were also from the minibuses, probably because they have less powerful engines. $\mathrm{SO}_{2}$ concentrations emitted by the analyzed buses were in a range of 9 - 362 ppmv.

Table 2 presents the results of $\mathrm{NO}_{2}$ and $\mathrm{SO}_{2}$ emissions from the exhaust of 8 trucks that passed by the BR101 highway, which crosses through the city of Campos dos Goytacazes, coming from large urban centers. These trucks were manufactured between the years of 1975 and 2010. In this case, the D-500S diesel was used by all

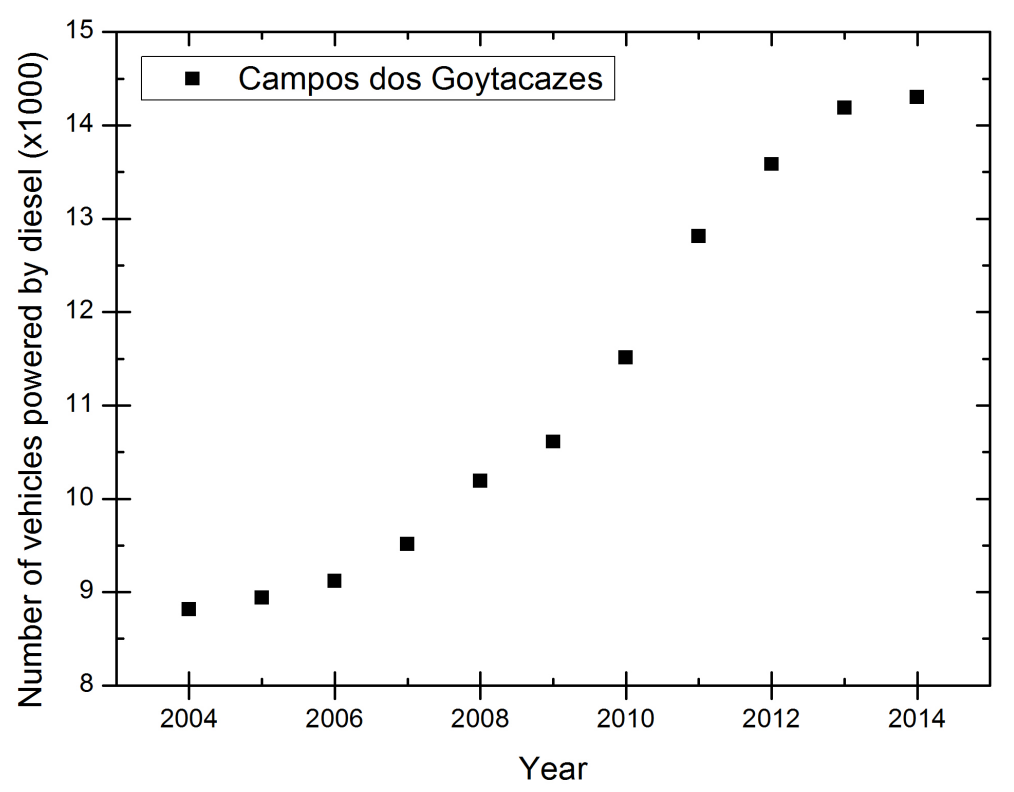

Figure 1. Increase in number of vehicles in Campos dos Goytacazes city by year. 


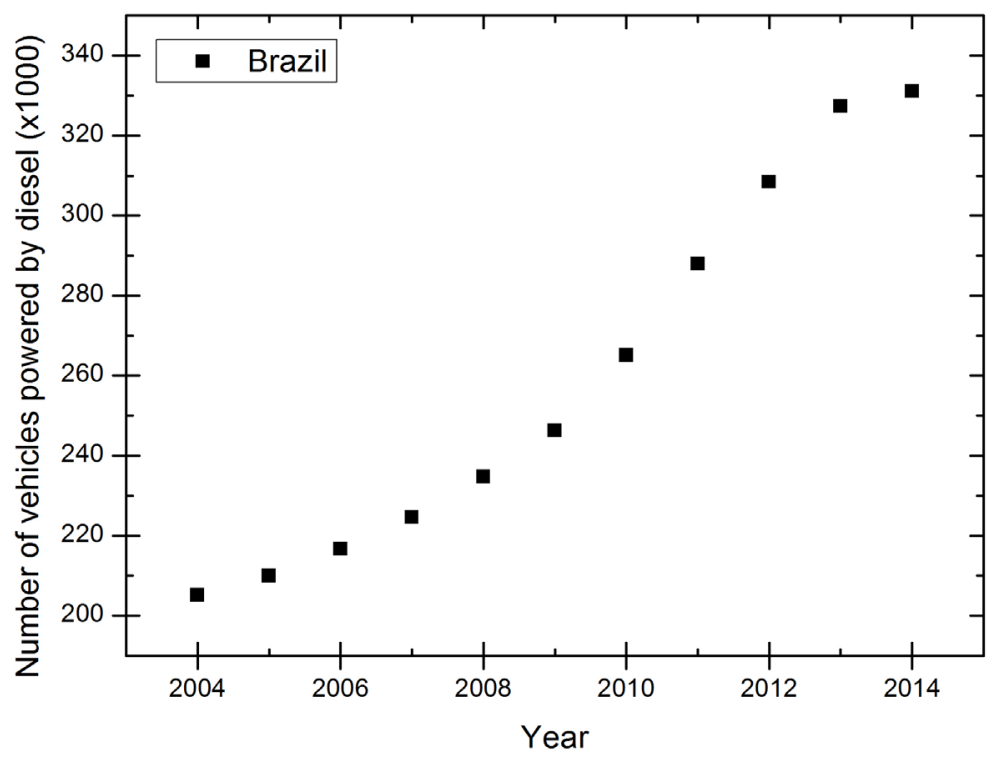

Figure 2. Increase in number of vehicles in Brazil by year.

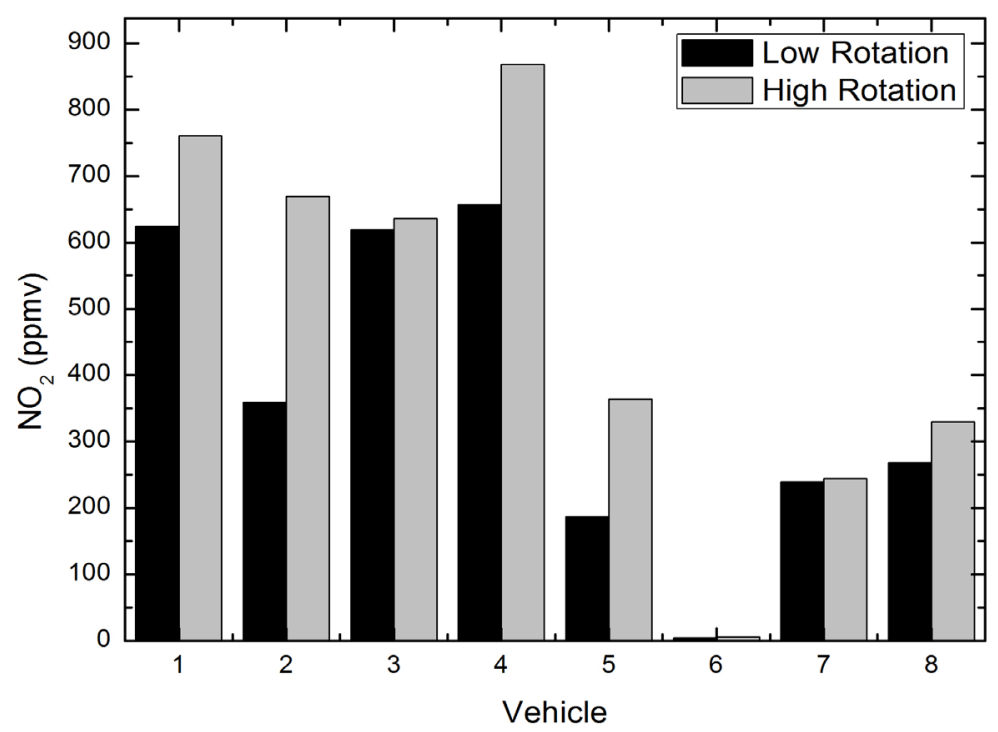

Figure 3. Nitrous oxide exhaust emissions from buses.

Table $1 . \mathrm{NO}_{2}$ and $\mathrm{SO}_{2}$ emissions gases from the exhaust in buses.

\begin{tabular}{cccccccc}
\hline \multirow{2}{*}{ Vehicle } & \multirow{2}{*}{ Brand } & Year & \multicolumn{2}{c}{ Low Rotation } & Low Rotation & High Rotation & High Rotation \\
\cline { 3 - 7 } & & & \multicolumn{2}{c}{$\mathrm{NO}_{2}(\mathrm{ppmv})$} & $\mathrm{SO}_{2}(\mathrm{ppmv})$ & $\mathrm{NO}_{2}(\mathrm{ppmv})$ & $\mathrm{SO}_{2}(\mathrm{ppmv})$ \\
\hline 1 & Bus & Mercedes & 1980 & 624 & 307 & 761 & 300 \\
2 & Bus & Mercedes & 1981 & 359 & 280 & 669 & 354 \\
3 & Bus & Mercedes & 1985 & 619 & 299 & 636 & 259 \\
4 & Bus & Mercedes & 1989 & 657 & 301 & 368 & 362 \\
5 & Bus & Mercedes & 2001 & 187 & 93 & 6 & 155 \\
6 & Minibus & Iveco & 2003 & 4 & 9 & 244 & 9 \\
7 & Bus & Mercedes & 2006 & 239 & 249 & 330 & 253 \\
8 & Bus & Mercedes & 2006 & 268 & 172 & & 191 \\
\hline
\end{tabular}




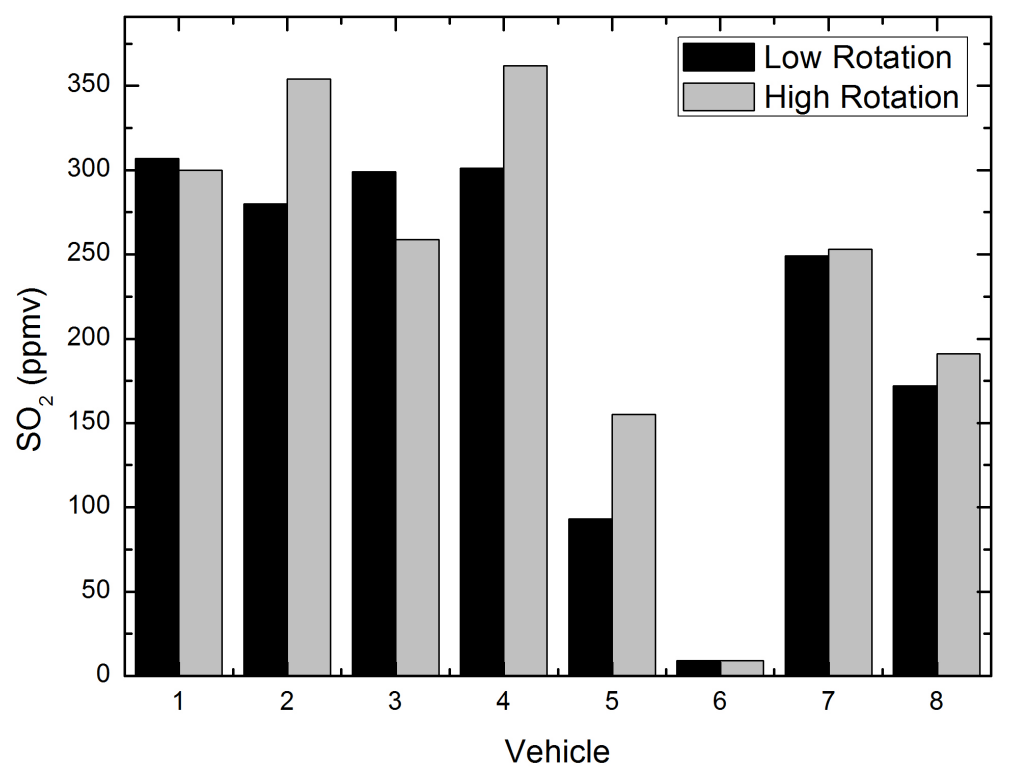

Figure 4. Sulfur dioxide exhaust emissions from buses.

Table 2. $\mathrm{NO}_{2}$ and $\mathrm{SO}_{2}$ emissions gases from the exhaust in trucks.

\begin{tabular}{|c|c|c|c|c|c|c|c|}
\hline \multirow{3}{*}{$\begin{array}{c}\text { Vehicle } \\
9\end{array}$} & \multirow{3}{*}{$\begin{array}{l}\text { Brand } \\
\text { Truck }\end{array}$} & \multirow{3}{*}{$\begin{array}{c}\text { Year } \\
\text { Mercedes }\end{array}$} & \multirow{2}{*}{\multicolumn{2}{|c|}{$\begin{array}{l}\text { Low Rotation } \\
\mathrm{NO}_{2} \text { (ppmv) }\end{array}$}} & \multirow{3}{*}{$\begin{array}{c}\text { Low Rotation } \\
\mathrm{SO}_{2} \text { (ppmv) } \\
52\end{array}$} & \multirow{3}{*}{$\begin{array}{c}\text { High Rotation } \\
\mathrm{NO}_{2} \text { (ppmv) } \\
11\end{array}$} & \multirow{3}{*}{$\begin{array}{c}\text { High Rotatior } \\
\mathrm{SO}_{2} \text { (ppmv) } \\
55\end{array}$} \\
\hline & & & & & & & \\
\hline & & & 1975 & 11 & & & \\
\hline 10 & Truck & Mercedes & 1977 & 88 & 15 & 286 & 0 \\
\hline 11 & Truck & Mercedes & 1991 & 57 & 5 & 85 & 5 \\
\hline 12 & Truck & Wolks & 2002 & 48 & 25 & 106 & 55 \\
\hline 13 & Truck & Ford & 2005 & 92 & 24 & 136 & 10 \\
\hline 14 & Truck & Mercedes & 2006 & 28 & 6 & 46 & 3 \\
\hline 15 & Truck & Volvo & 2009 & 92 & 104 & 2 & 4 \\
\hline 16 & Truck & Scania & 2010 & 235 & 100 & 153 & 45 \\
\hline
\end{tabular}

trucks, which is commercialized in Brazilian metropolitan regions and has 500 ppm of sulfur in its formulation.

Analyzing $\mathrm{NO}_{2}$ emissions, we can notice that, in most of the sample, this gas tended to be emitted mostly in the accelerated operation mode than in the non-accelerated mode (Figure 5), possibly due to higher fuel consumption in higher engine rotation speed. However, the vehicles 15 and 16 presented different behavior. The analyzed trucks emitted $\mathrm{NO}_{2}$ gas in concentrations between 2 and 286 ppmv.

Analyzing $\mathrm{SO}_{2}$ emission, only trucks 9 and 12 presented higher emission concentrations in the accelerated operation mode. The others showed different behavior. The trucks emitted $\mathrm{SO}_{2}$ gas in concentrations between 2 and 104 ppmv (Figure 6).

If we compare $\mathrm{SO}_{2}$ emissions on Table 1 and Table 2, $\mathrm{SO}_{2}$ gas emission is greater from buses than from trucks. This factor is possibly connected to the use of fuel, once the buses are part of the public transportation fleet and were supplied with Petrobras standard diesel (D-2000S), while the trucks driving along the BR101 highway came from metropolitan areas and were supplied with metropolitan Petrobras standard diesel D-500S. This behavior was also noted for $\mathrm{NO}_{2}$ gas, once buses emitted this gas in higher concentrations than trucks.

$\mathrm{NO}_{2}$ and $\mathrm{SO}_{2}$ were detected in most vehicles with high concentrations (ppmv) as shown in Table 1 and Table 2, leading to a serious environmental and social problem, since these gases are precursors of tropospheric ozone. Tropospheric ozone is a major constituent of photochemical smog, generates acid rain, reduces the ozone layer and it is harmful to human health. 


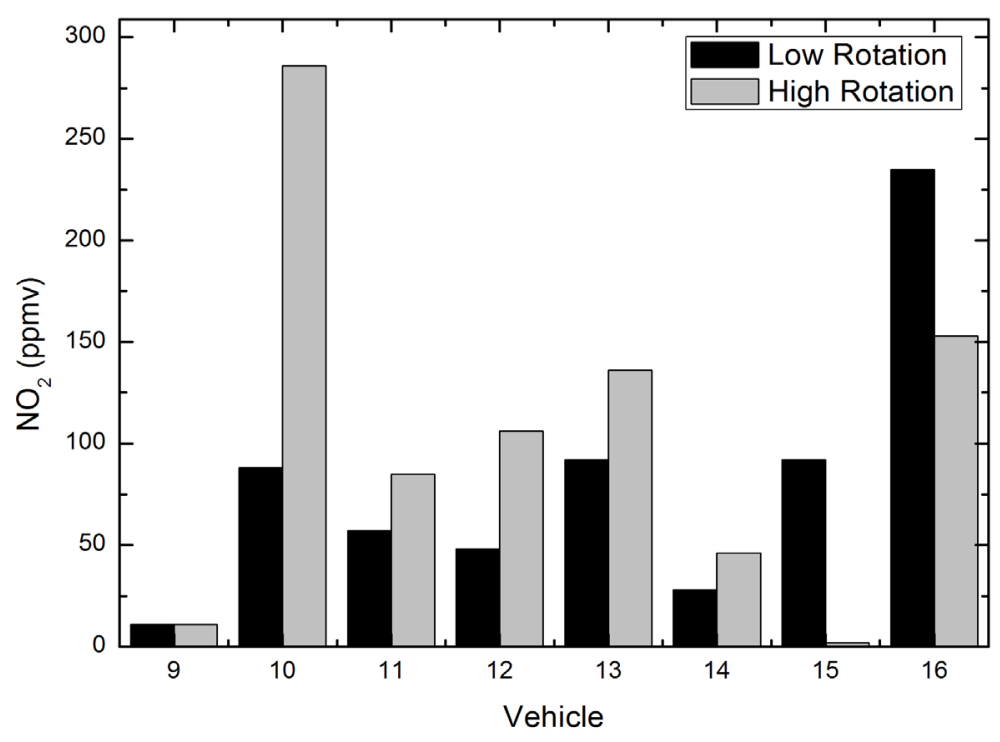

Figure 5. Nitrous oxide exhaust emissions from trucks.

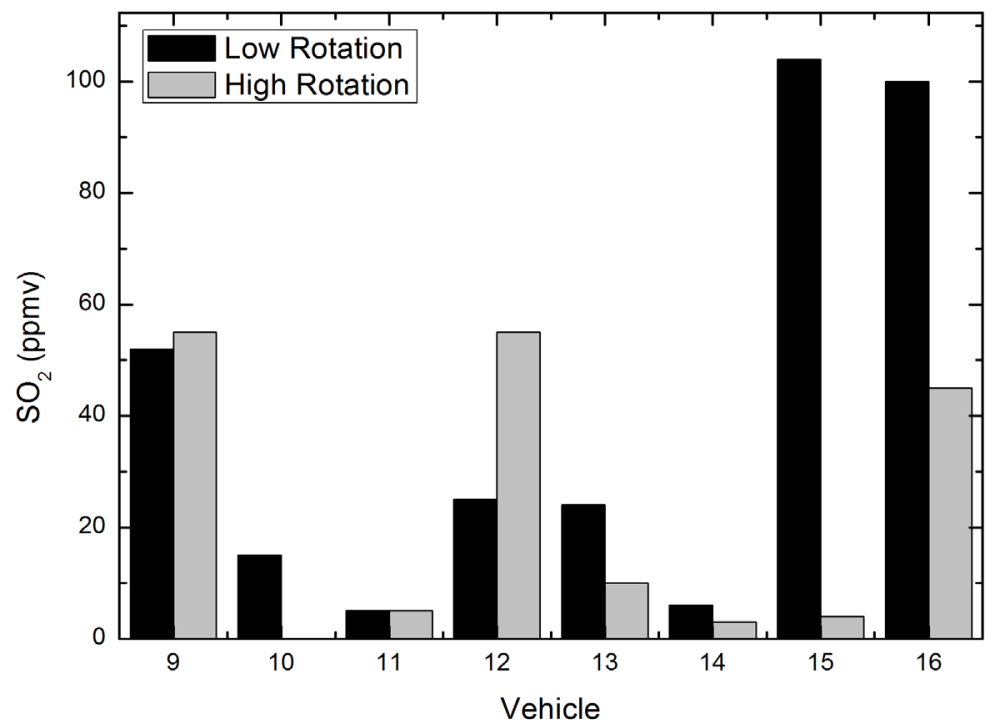

Figure 6. Sulfur dioxide exhaust emissions from trucks.

The emission of particulate material is related with the burning of diesel fuel and lubricant oil and with the wear on the engine bearings and materials. Particulate emissions in diesel cycle engines are considerably larger than in Otto cycle engines. Table 3 presents various constituents of the soot, which was accumulated on the filters used in the gas collection from the exhaust of buses and trucks engines.

Elements such as $\mathrm{Zn}$, Ni and $\mathrm{Cu}$ probably derived from the degradation of structural metal parts of the engine and are harmful to be inhaled by humans. Elements such as $\mathrm{Mn}, \mathrm{Cr}$, Fe, probably derived from the internal corrosion of stainless steel components, mainly chromium, which is a heavy metal, highly toxic for humans. Elements such as Si may be derived from a possible contamination of the sample with the environmental dust. P residues may come from the contamination of detergent and lubricant additives, while $\mathrm{K}$ and $\mathrm{Ca}$ may be residues of the catalysts, such as $\mathrm{KOH}$ and $\mathrm{CaOH}$, respectively.

In Table 3, we can notice a difference in the composition particulate sulfur emitted in buses and trucks. In truck exhausts, this component presented lower concentration than in the bus ones. This difference is probably due to the fact that the fuel used by buses has a greater concentration of sulfur (D-2000S) than the fuel used by trucks (D-500S), which reinforces the need for public policies for reducing pollution. 
Table 3. Element analysis of a sample particulate by EDS-XRF.

\begin{tabular}{ccc}
\hline \multirow{2}{*}{ Element } & \multicolumn{2}{c}{ Concentrations of particulate per sample (wt\%) } \\
\cline { 2 - 3 } & Bus & Truck \\
\hline $\mathrm{S}$ & 52.67 & 30.08 \\
$\mathrm{Fe}$ & 16.51 & 22.24 \\
$\mathrm{Si}$ & 11.83 & 7.63 \\
$\mathrm{Ca}$ & 9.00 & 23.82 \\
$\mathrm{Zn}$ & 2.95 & 12.10 \\
$\mathrm{P}$ & 1.85 & 2.11 \\
$\mathrm{Ni}$ & 1.37 & 0.29 \\
$\mathrm{Cr}$ & 0.69 & 0.56 \\
$\mathrm{Ti}$ & 0.62 & 0.44 \\
$\mathrm{Mn}$ & 0.31 & 0.49 \\
$\mathrm{Cu}$ & 0.18 & 0.24 \\
\hline
\end{tabular}

\section{Conclusions}

Electrochemical sensors proved to be sensitive and selective to detect and quantify the gases $\mathrm{NO}_{2}$ and $\mathrm{SO}_{2}$. Using electrochemical sensors, it was possible to measure these gases on the exhaust of buses and trucks in ppmv concentrations. X-ray Fluorescence Spectroscopy intended to identify the constituent elements of the soot from the bus and truck exhaust.

In Brazil, there are more than 1 million buses and trucks. Many of them with over 15 years of use are in bad conditions. In June 2013, this fact triggered popular manifestations challenging the increase in bus fares, considered much expensive with low service quality. These protests began in the city of São Paulo and have spread throughout the country, where millions of people crowded the streets of major Brazilian cities to manifest for improvements in the transportation sector.

The government has given priority to individual transportation, leading to increased car sales and consequently traffic congestion in large cities. This reduces the logistics of people transit and negatively impact important sectors of the economy. In the trucking industry, the option for the majority use of road transport generates difficulties in exportation of agricultural products, delivery delays and economic losses.

The implementation of public policies that prioritize quality public transportation, including trains, subways, light rail transit (LRT) and special lanes for buses is required. Furthermore, the government must establish strict environmental legislation to limit the emission of gases and particles by the transportation sector, encouraging the use of more environmentally sustainable fuels.

\section{Acknowledgements}

The authors would like to thank Luiz Antonio M. Meirelles and Vanuzia A. dos Santos Ferreira for the assistance and contribution to the realization of this work.

\section{References}

[1] Hansen, J., Sato, M. and Ruedy, R. (2012) Perception of Climate Change. Proceedings of the National Academy of Sciences, 109, E2415-E2423. http://dx.doi.org/10.1073/pnas.1205276109

[2] Stocker, T.F. (2013) The Closing Door of Climate Targets. Science, 339, 280-282. http://dx.doi.org/10.1126/science.1232468

[3] Randerson, J.T. (2013) Climate Science: Global Warming and Tropical Carbon. Nature, 494, 319-320. http://dx.doi.org/10.1038/nature11949 
[4] Cox, P.M., Pearson, D., Booth, B.B., Friedlingstein, P., Huntingford, C., Jones, C.D. and Luke, C.M. (2013) Sensitivity of Tropical Carbon to Climate Change Constrained by Carbon Dioxide Variability. Nature, 494, 341-344. http://dx.doi.org/10.1038/nature11882

[5] Solomon, S., Plattner, G.-K., Knutti, R. and Friedlingstein, P. (2009) Irreversible Climate Changes Due to Carbon Dioxide Emissions. Proceedings of the National Academy of Sciences of the United States of America, 106, 1704-1709. http://dx.doi.org/10.1073/pnas.0812721106

[6] Meinshausen, M., Meinshausen, N., Hare, W., Raper, S.C.B., Frieler, K., Knutti, R., Frame, D.J. and Allen, M.R. (2009) Greenhouse-Gas Emission Targets for Limiting Global Warming to $2^{\circ} \mathrm{C}$. Nature, 458, 1158-1162. http://dx.doi.org/10.1038/nature08017

[7] Allen, M.R., Frame, D.J., Huntingford, C., Jones, C.D., Lowe, J.A., Meinshausen, M. and Meinshausen, N. (2009) Warming Caused by Cumulative Carbon Emissions towards the Trillionth Tonne. Nature, 458, 1163-1166. http://dx.doi.org/10.1038/nature08019

[8] Hansen, J., et al. (2008) Target Atmospheric $\mathrm{CO}_{2}$ : Where Should Humanity Aim? In Press, arXiv:0804.1126.

[9] Trenberth, K.E., Moore, B., Karl, T.R. and Nobre, C. (2006) Monitoring and Prediction of the Earth’s Climate: A Future Perspective. Journal of Climate, 19, 5001-5008. http://dx.doi.org/10.1175/JCLI3897.1

[10] Hansen, J. and Sato, M. (2004) Greenhouse Gas Growth Rates. Proceedings of the National Academy of Sciences of the United States of America, 101, 16109-16114. http://dx.doi.org/10.1073/pnas.0406982101

[11] Beck, J. (2013) Predicting Climate Change Effects on Agriculture from Ecological Niche Modeling: Who Profits, Who Loses? Climatic Change, 116, 177-189. http://dx.doi.org/10.1007/s10584-012-0481-x

[12] Rockström, J., Steffen, W., Noone, K., Persson, Å., Chapin, F.S., Lambin, E.F., et al. (2009) A Safe Operating Space for Humanity. Nature, 461, 472-475. http://dx.doi.org/10.1038/461472a

[13] Flynn, K.J., Blackford, J.C., Baird, M.E., Raven, J.A., Clark, D.R., Beardall, J., et al. (2012) Changes in pH at the Exterior Surface of Plankton with Ocean Acidification. Nature Climate Change, 2, 510-513. http://dx.doi.org/10.1038/nclimate1696

[14] Gillett, N.P., Stone, D.A., Stott, P.A., Nozawa, T., Karpechko, A.Y., Hegerlet, G.C., et al. (2008) Attribution of Polar Warming to Human Influence. Nature Geoscience, 1, 750-754. http://dx.doi.org/10.1038/ngeo338

[15] Santer, B.D., Wigley, T.M.L., Gleckler, P.J., Bonfils, C., Wehner, M.F., AchutaRao, K., et al. (2006) Forced and Unforced Ocean Temperature Changes in Atlantic and Pacific Tropical Cyclogenesis Regions. Proceedings of the National Academy of Sciences, 103, 13905-13910. http://dx.doi.org/10.1073/pnas.0602861103

[16] Janssen, M. (1998) Use of Complex Adaptive Systems for Modeling Global Change. Ecosystems, 1, 457-463. http://dx.doi.org/10.1007/s100219900041

[17] Kurz, W.A., Dymond, C.C., Stinson, G., Rampley, G.J., Neilson, E.T., Carroll, A.L., et al. (2008) Mountain Pine Beetle and Forest Carbon Feedback to Climate Change. Nature, 452, 987-990. http://dx.doi.org/10.1038/nature06777

[18] Lenoir, J., Gegout, J.C., Marquet, P.A., de Ruffray, P. and Brisse, H. (2008) A Significant Upward Shift in Plant Species Optimum Elevation during the 20th Century. Science, 320, 1768-1771. http://dx.doi.org/10.1126/science.1156831

[19] Rosenzweig, C., Karoly, D., Vicarelli, M., Neofotis, P., Wu, Q.G., Casassa, G., et al. (2008) Attributing Physical and Biological Impacts to Anthropogenic Climate Change. Nature, 453, 353-357. http://dx.doi.org/10.1038/nature06937

[20] Lloyd, A.C. and Cackette, T.A. (2001) Diesel Engines: Environmental Impact and Control. Journal of the Air \& Waste Management Association, 51, 809-847. http://dx.doi.org/10.1080/10473289.2001.10464315

[21] Schramm, D.U., Sthel, M.S., da Silva, M.G., Carneiro, L.O., Junior, A.J.S., Souza, A.P. and Vargas, H. (2003) Application of Laser Photoacoustic Spectroscopy for the Analysis of Gas Samples Emitted by Diesel Engines. Infrared Physics \& Technology, 44, 263-269. http://dx.doi.org/10.1016/S1350-4495(03)00125-7

[22] McCulloch, M.T., Langford, N. and Duxbury, G. (2005) Real-Time Trace-Level Detection of Carbon Dioxide and Ethylene in Car Exhaust Gases. Applied Optics, 44, 2887-2894. http://dx.doi.org/10.1364/AO.44.002887

[23] Carvalho, A.L.N., Annoni, R., Torres, L.H.L., Durão, A.C.C.S., Shimada, A.L.B., Almeida, F.M., et al. (2013) Anacardic Acids from Cashew Nuts Ameliorate Lung Damage Induced by Exposure to Diesel Exhaust Particles in Mice. Evidence-Based Complementary and Alternative Medicine, 2013, 1-13. http://dx.doi.org/10.1155/2013/549879

[24] Veras, M.M., Guimarães-Silva, R.M., Caldini, E.G., Saldiva, P.H.N., Dolhnikoff, M. and Mayhew, T.M. (2012) The Effects of Particulate Ambient Air Pollution on the Murine Umbilical Cord and Its Vessels: A Quantitative Morphological and Immunohistochemical Study. Reproductive Toxicology, 34, 598-606. http://dx.doi.org/10.1016/j.reprotox.2012.08.003

[25] Carvalho-Oliveira, R. (2005) Diesel Emissions Significantly Influence Composition and Mutagenicity of Ambient Particles: A Case Study in São Paulo, Brazil. Environmental Research, 98, 1-7. 
http://dx.doi.org/10.1016/j.envres.2004.05.007

[26] Baird, C. (2002) Química Ambiental. 2nd Edition, Bookman, Porto Alegre.

[27] Bosch, R. (2005) Manual de Tecnologia Automotiva. 25th Edition, Edgard Blucher, São Paulo.

[28] da Silva Ribeiro, G., Botelho, M.L. and de Oliveira, L.D. (2013) As Manifestações de Junho de 2013. Revista Continentes, 2, 116-141.

[29] Carneiro, T.L. (2014) Da “Imobilidade” à Ação: Por que os Brasileiros Saíram às Ruas em Junho de 2013 ? O Contágio Comportamental como Parte da Explicação. E-Legis-Revista Eletrônica do Programa de Pós-Graduação da Câmara dos Deputados, 14, 26-45.

[30] Santos, E.H. (2014) Crise de Representação Política no Brasil e os Protestos de Junho de 2013 Crisis of Political Representation in Brazil and the Protests of June 2013. Liinc em Revista, 10, 86-95.

[31] Da Silva, C.B.P., Saldiva, P.H.N., Amato-Lourenço, L.F., Rodrigues-Silva, F. and El Khouri Miraglia, S.G. (2012) Evaluation of the Air Quality Benefits of the Subway System in São Paulo, Brazil. Journal of Environmental Management, 101, 191-196. http://dx.doi.org/10.1016/j.jenvman.2012.02.009

[32] Torricelli, A.A.M., Novaes, P., Matsuda, M., Braga, A., Saldiva, P.H.N., Alves, M.R. and Monteiro, M.L.R. (2013) Correlation between Signs and Symptoms of Ocular Surface Dysfunction and Tear Osmolarity with Ambient Levels of Air Pollution in a Large Metropolitan Area. Cornea, 32, e11-e15. http://dx.doi.org/10.1097/ICO.0b013e31825e845d

[33] André, P.A.D., Veras, M.M., Miraglia, S.G. and Saldiva, P.H. (2012) Lean Diesel Technology and Human Health: A Case Study in Six Brazilian Metropolitan Regions. Clinics, 67, 639-646. http://dx.doi.org/10.6061/clinics/2012(06)15

[34] Fajersztajn, L., Veras, M., Barrozo, L.V. and Saldiva, P. (2013) Air Pollution: A Potentially Modifiable Risk Factor for Lung Cancer. Nature Reviews Cancer, 13, 674-678. http://dx.doi.org/10.1038/nrc3572

[35] Ferron, M.M., de Lima, A.K., Saldiva, P.H.N. and Gouveia, N. (2012) Environmental Lead Poisoning among Children in Porto Alegre State, Southern Brazil. Revista de Saúde Pública, 46, 226-233. http://dx.doi.org/10.1590/S0034-89102012000200004

[36] Miraglia, S.G.E.K., Veras, M.M., Amato-Lourenco, L.F., Rodrigues-Silva, F. and Saldiva, P.H.N. (2013) Follow-Up of the Air Pollution and the Human Male-to-Female Ratio Analysis in São Paulo, Brazil: A Times Series Study. BMJ Open, 3, 1-6. http://dx.doi.org/10.1136/bmjopen-2013-002552

[37] Rodrigues-Silva, F., de Paula Santos, U., Saldiva, P.H.N., Amato-Lourenço, L.F. and El Khouri Miraglia, S.G. (2012) Health Risks and Economic Costs of Absenteeism Due to Air Pollution in São Paulo, Brazil. Aerosol and Air Quality Research, 12, 826-833.

[38] Sánchez-Ccoyllo, O.R., Martins, L.D., Ynoue, R.Y. and de Fátima Andrade, M. (2007) The Impact on Tropospheric Ozone Formation on the Implementation of a Program for Mobile Emissions Control: A Case Study in São Paulo, Brazil. Environmental Fluid Mechanics, 7, 95-119. http://dx.doi.org/10.1007/s10652-007-9018-7

[39] Petrobrás, S.A. (2014) Mercado do Petróleo Brasileiro. http://www.petrobras.com.br

[40] Atkinson, R. (2000) Atmospheric Chemistry of VOCs and NOX. Atmospheric Environment, 34, 2063-2101. http://dx.doi.org/10.1016/S1352-2310(99)00460-4

[41] Wolff, G.T. and Korsog, P.E. (1992) Ozone Control Strategies Based on the Ratio of Volatile Organic Compounds to Nitrogen Oxides. Journal of the Air \& Waste Management Association, 42, 1173-1177. http://dx.doi.org/10.1080/10473289.1992.10467064

[42] Seinfeld, J.H. and Pandis, S.N. (2006) Atmospheric Chemistry and Physics: From Air Pollution to Climate Change. 2nd Edition, John Wiley \& Sons, New York.

[43] McGonigle, A.J.S., Thomson, C.L., Tsanev, V.I. and Oppenheimer, C. (2004) A Simple Technique for Measuring Power Station $\mathrm{SO}_{2}$ and $\mathrm{NO}_{2}$ Emissions. Atmospheric Environment, 38, 21-25. http://dx.doi.org/10.1016/j.atmosenv.2003.09.048

[44] Xie, Z., et al. (2009) Effects of Precipitation Variation on Severe Acid Rain in Southern China. Journal of Geographical Sciences, 19, 489-501. http://dx.doi.org/10.1007/s11442-009-0489-y

[45] Agency, U.S.E.P. (2014) Carbon Monoxide Health and Environmental Impacts of CO. http://www.epa.gov/airquality/carbonmonoxide/

[46] Brook, R.D., et al. (2004) Air Pollution and Cardiovascular Disease: A Statement for Healthcare Professionals from the Expert Panel on Population and Prevention Science of the American Heart Association. Circulation, 109, 2655-2671. http://dx.doi.org/10.1161/01.CIR.0000128587.30041.C8

[47] Townsend, C. and Maynard, R. (2002) Effects on Health of Prolonged Exposure to Low Concentrations of Carbon Monoxide. Occupational and Environmental Medicine, 59, 708-711. http://dx.doi.org/10.1136/oem.59.10.708

[48] Maitre, A., et al. (2006) Impact of Urban Atmospheric Pollution on Coronary Disease. European Heart Journal, 27, 2275-2284. http://dx.doi.org/10.1093/eurheartj/ehl162 
[49] Lee, Y., et al. (2003) Climate, Traffic-Related Air Pollutants and Allergic Rhinitis Prevalence in Middle-school Children in Taiwan. European Respiratory Journal, 21, 964-970. http://dx.doi.org/10.1183/09031936.03.00094602

[50] Chou, J. (2000) Hazardous Gas Monitors: A Practical Guide to Selection, Operation and Applications. McGraw-Hill Professional, New York.

[51] DETRAN (2014) Departamento Estadual de Trânsito. http://www.detran.rj.gov.br/

[52] Mello, R. (2008) Desenvolvimento de Sensores de Gases à Base de Ferritas do Tipo $\mathrm{MFe}_{2} \mathrm{O}_{4}(\mathrm{M}=\mathrm{Mn}$, Zn e Ni). Physics Master Degree Dissertation, Maringá State University, Paraná.

[53] Bard, A.J. and Faulkner, L.R. (1980) Electrochemical Methods: Fundamentals and Applications. Wiley, New York.

[54] Bertin, E.P. (1975) Principles and Practice of X-Ray Spectrometric Analysis. Plenum Press, New York. http://dx.doi.org/10.1007/978-1-4613-4416-2

[55] Jenkins, R. (1995) Quantitative X-Ray Spectrometry. CRC Press, Boca Rato.

[56] Moraes, L.M.B.D. (2009) Utilização da técnica de fluorescência de raios X por dispersão em energia (EDXRF) na avaliação do material particulado em suspensão na cidade de Limeira-SP. Universidade de São Paulo, São Paulo. 
Scientific Research Publishing (SCIRP) is one of the largest Open Access journal publishers. It is currently publishing more than 200 open access, online, peer-reviewed journals covering a wide range of academic disciplines. SCIRP serves the worldwide academic communities and contributes to the progress and application of science with its publication.

Other selected journals from SCIRP are listed as below. Submit your manuscript to us via either submit@scirp.org or Online Submission Portal.
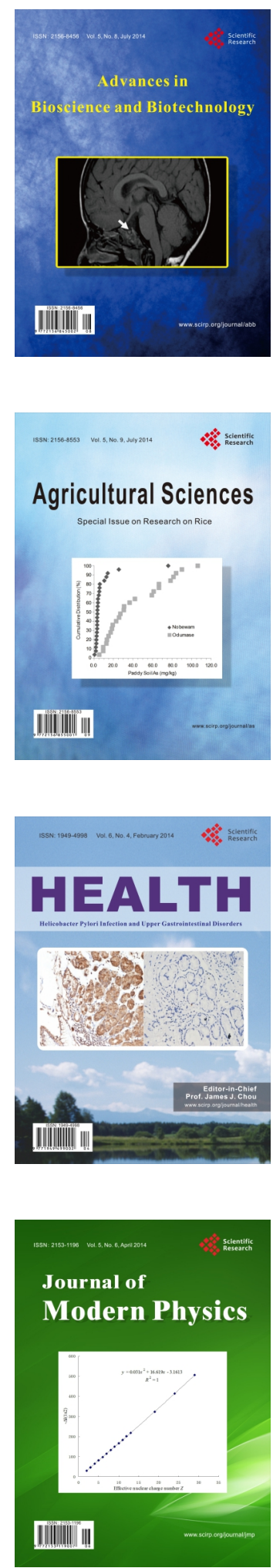
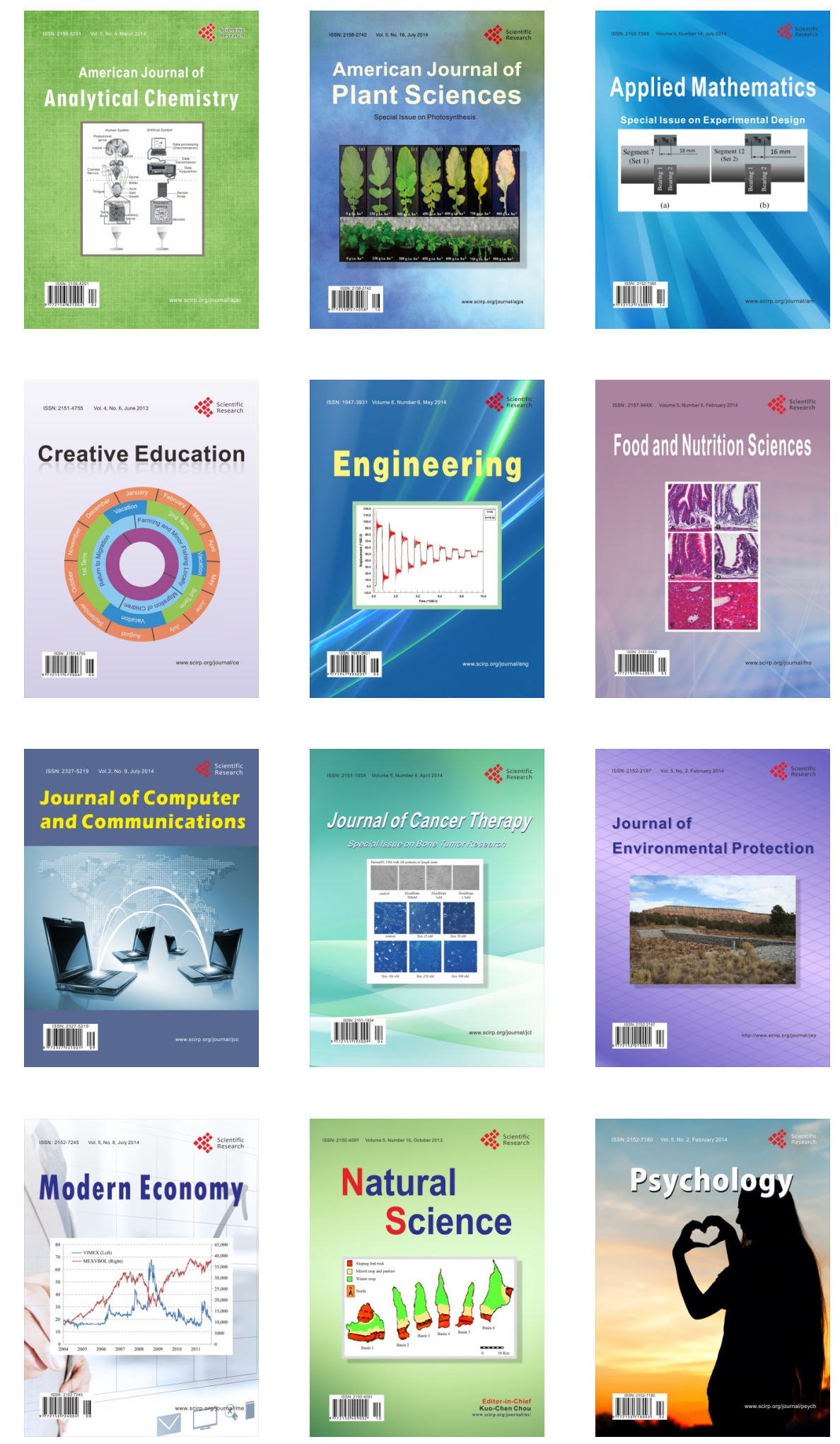